\title{
Internships in Special Collections: Experiential Pedagogy, Intentional Design, and High-Impact Practice
}

Archives and special collections can be sites of deep, experiential learning for college students, through hands-on engagement with primary sources in reading rooms or classrooms and through mentored learning experiences like practicums or internships. Internships are a well-established component of formal education and training in the library and archives field, and many special collections and archives host internships for graduate students in library science and archives certificate programs; some institutions also host undergraduate student internships. Internships are recognized as a way for future archivists and special collections librarians to gain training and experience, "to connect the skills and knowledge gained" in coursework to day-to-day professional practice, and to "[engage] in meaningful work under the mentorship of experienced ... professionals." ${ }^{1}$ For libraries and archives, an internship is often a useful means for allotting additional manpower to projects like processing or cataloging backlogs, for promoting collections, or for recruitment.

Beyond the practical needs of host sites, "learning by doing" through internships can provide highly valuable experiences for students, not just for career exploration and future job placement, but for enhancing academic achievement, personal growth, and other positive educational outcomes. Internships are widely promoted to students to provide paths for exploring career interests and to acquire professional skills and experience in their current or future fields of study. ${ }^{2}$ Recent research has shown internships to have positive impacts on $\mathrm{GPA}^{3}$ and to increase undergraduate and graduate students' personal competencies such as multicultural awareness and time

1. Society of American Archivists, Best Practices for Internships as a Component of Graduate Archival Education (2008), available online at https: / / www2.archivists.org/sites/all / files / BestPract-Internships.pdf [accessed 18 April 2018].

2. Nancy O’Neill, “Internships as a High-Impact Practice: Some Reflections on Quality," $A A C \& U$ Peer Review 12, no. 4 (Fall 2010): 4-8.

3. Eugene T. Parker III, Cindy A. Kilgo, Jessica K. Ezell Sheets, and Ernest T. Pascarella, "The Differential Effects of Internship Participation on End-of-Fourth-Year GPA by Demographic and Institutional Characteristics," Journal of College Student Development 57, no. 1 (Jan. 2016): 104-09.

๑ 2019 by Maggie Gallup Kopp (CC BY-NC [https://creativecommons.org/licenses/by-nc/4.0/]). 
management skills. ${ }^{4}$ These positive benefits are a major reason why the Association of American Colleges and Universities (AAC\&U), National Society for Experiential Education (NSEE), and other professional associations in higher education have encouraged colleges and universities to seek ways to integrate internships into the undergraduate curriculum. ${ }^{5}$ As colleges and universities seek to implement and measure programs and practices that foster student development and academic success, archives and special collections can directly contribute to campus goals for student engagement by creating well-designed, high-quality mentored and experiential learning opportunities to interns, whether at the graduate or undergraduate level.

One challenge of implementing internship programs in archives and special collections is that students arrive at their internships with varied levels of competency with theories, practices, and tools that are normally acquired through education and employment in the field. It can be tempting to design internships that revolve around project-based tasks or rote work rather than the types of learning that contribute to students' overall educational experience. However, a focus on "intentional learning shaped by experiential pedagogy"6 is key to building a strong internship program that meets current standards and best practices in higher education. At Brigham Young University's L. Tom Perry Special Collections, the desire to create high-impact educational experiences for our undergraduate interns prompted an overhaul of our longstanding program. A review of best practices for internships and a backward design-inspired approach led to the creation of an explicitly pedagogy-focused internship structured around learning goals rather than project-based performance. This paper describes the design, implementation, and impact of the internship program, and the benefits of aligning internship programs with national best practices and standards for internships in the library and archives profession and in higher education.

\section{Internships at L. Tom Perry Special Collections}

The L. Tom Perry Special Collections at BYU's Harold B. Lee Library has historically offered volunteer internships to undergraduates based on the university's undergraduate teaching focus and large undergraduate student population, ${ }^{7}$ as well

4. Lori Simons, "Lessons Learned from Experiential Learning: What Do Students Learn from a Practicum/Internship?" International Journal of Teaching and Learning in Higher Education 24, no. 3 (2012): 325-34.

5. See Association of American Colleges and Universities, College Learning for the New Global Century: A Report from the National Leadership Council for Liberal Education and America's Promise (Washington, DC, 2007); Robert P. Inkster and Roseanna Gaye Ross, The Internship as Partnership: A Handbook for Campusbased Coordinators and Advisors (Raleigh, NC: National Society for Experiential Education, 2005); and Council for the Advancement of Standards (CAS) in Higher Education, Professional Standards for Higher Education: Internship Programs (Washington, DC, 2015).

6. CAS, Professional Standards for Higher Education: Internship Programs, 310.

7. For 2017-2018, BYU enrolled 30,693 undergraduate students, which represents about 91 percent of total student enrollment ( 35 percent of students come from Utah). See BYU News Facts and Figures, available online at http://news.byu.edu/byu-numbers [accessed 18 April 2018]. 
as recruitment needs in a state that lacks a residential MLS program. ${ }^{8}$ The program was reviewed in 2015, prompted by personnel changes in Special Collections, greater university emphasis on experiential learning practices in academic programs, and concerns from BYU Human Resources about whether campus volunteers were meeting professional and federal guidelines for unpaid internships. It became apparent that the existing program was not meeting best practices for academic internships, nor was it consistently providing quality learning experiences for students.

Interns would typically be paired with a single archives or rare books curator who would assign the student one or more projects to work on throughout the semester. As a result, undergraduate internship experiences were primarily focused on task completion and could vary widely by project quantity and quality. While interns learned how to do specific tasks and enjoyed working with special collections materials, supervisors often did not have the time to contextualize projects within the mission and goals of the library. Feedback from both undergraduate interns and department mentors made it clear that internships were failing to fully provide students with adequate career exploration experiences, including a broad introduction to the library and archives profession. Though one intent of the internship program was to introduce undergraduates to the wide variety of work in Perry Special Collections, most interns would only get a brief look at areas outside their supervisors' purview (if at all) because they were so busy working on projects for their mentoring curators.

The lack of opportunities for learning about professional values and practice combined with the rote nature of most of the assignments meant that our internships were looking more like unpaid work-study programs than learning experiences. In fact, since interns were performing the same tasks that the department hires undergraduate students to perform, the internship program could perhaps be construed as using unpaid interns to displace employees - a questionable practice from both an ethical and professional standpoint. It was time to revamp the existing undergraduate internship program at Perry Special Collections and make changes that would improve students' experiences to better align them with university goals for student engagement.

\section{Considerations for Designing Internships}

There are no formal professional standards for internships within the library or archives fields, though the Society of American Archivists has issued a guidelines document Best Practices for Internships as a Component of Graduate Archival Educa-

8. Maggie Gallup Kopp and John M. Murphy, "Mentored Learning in Special Collections: Undergraduate Archival and Rare Books Internship," Journal of Library Innovation 3 (2012): 50-62; Connie Lamb, Brittany Hendricks, and Quinn D. Galbraith, "Growing the Profession: Mentoring Undergraduates for Librarianship,” College \& Undergraduate Libraries 22, no. 2 (2015): 123-48. 
tion (revised and approved in 2008, see reference 1 above). Jeannette A. Bastian and Donna Webber published a well-regarded practical guide to establishing and managing archival internships that same year. ${ }^{9}$ However, in the ensuing decade, a growing attention to high-impact educational practices in higher education and court rulings about unpaid internships have led to the articulation of several educational and legal standards and guidelines for internships with which internship providers in libraries and archives should be familiar.

The Council for the Advancement of Standards in Higher Education has created standards and guidelines for college and university internship programs that call for designing programs around student learning and development: "whether the internship is for credit or not, the focus must be on learning and educational objectives, not just on hours accrued at the site." ${ }^{10}$ The expectation that internship programs emphasize educational goals also underpins current interpretations of labor regulations concerning internships. In the United States, the Department of Labor uses a six-factor test to determine whether interns are subject to minimum wage requirements under the Fair Labor Standards Act. While "unpaid internships in the public sector and for non-profit charitable organizations, where the intern volunteers without expectation of compensation, are generally permissible," in order for programs to qualify for wage exemption, interns should not displace regular employees of the host institution and internships should be

structured around a classroom or academic experience as opposed to the employer's actual operations... The more the internship provides the individual with skills that can be used in multiple employment settings, as opposed to skills particular to one employer's operation, the more likely the intern would be viewed as receiving training. ${ }^{11}$

Many special collections and archives specifically offer unpaid, volunteer internships, whether to graduate or undergraduate students. In 2015, in the wake of high-profile labor disputes involving unpaid interns at major US corporations, federal courts ${ }^{12}$ have clarified that, under the Fair Labor Standards Act, volunteer internships are broadly protected as long as they are "designed chiefly for educational purposes and the majority of the benefit derived from the experience is to

9. Jeanette A. Bastian and Donna Webber, Archival Internships: A Guide for Faculty, Supervisors and Students (Chicago, IL: Society of American Archivists, 2008).

10. CAS, Professional Standards for Higher Education: Internship Programs, 314.

11. United States Department of Labor Wage and Hour Division, "Fact Sheet \#71: Internship Programs under the Fair Labor Standards Act" (2010), available online at https: / www.dol.gov/whd/regs/ compliance/whdfs71.pdf [accessed 18 April 2018].

12. Glatt v. Fox Searchlight Pictures, Inc., No. 13-4478-cv (2d Cir. July 2, 2015); Wang v. Hearst Corp, No. 13-4480-cv (2d Cir. July 2, 2015). 
the intern" rather than the institution. ${ }^{13}$ To conform to this standard, institutions should take care to intentionally design internships around pedagogical goals and practices rather than using internships as opportunities to complete projects or assign busywork like filing and other clerical tasks. ${ }^{14}$

Literature on high-impact educational practices in higher education also provides clear guidance about elements to consider in designing a learning-focused internship program. The term "high-impact practices" has circulated in higher education over the last decade since the AAC\&U released a 2008 report, High-Impact Educational Practices: What They Are, Who Has Access to Them, and Why They Matter. Concerns about retention rates have spurred colleges and universities to examine student engagement, or "the time and effort students devote to activities that are empirically linked to desired outcomes of college and what institutions do to induce students to participate in these activities." ${ }^{15}$ Internships were one of several "high-impact" educational programs and practices identified in the AAC $\& U$ report that have been shown to increase students' academic performance and intellectual and personal development. ${ }^{16}$

According to the 2008 AAC\&U report, high-impact practices: 1) are effortful; 2) help students build substantive relationships; 3) help students engage across differences; 4) provide students with rich feedback; 5) help students apply and test what they are learning in new situations; and 6) provide opportunities for students to reflect on the people they are becoming. These qualities, when present, contribute to positive educational outcomes for students by reinforcing subject knowledge and by promoting other measures of student development like problem-solving, multicultural skills, and personal well-being. ${ }^{17}$ Nancy O’Neill elaborates on these characteristics of high-impact practices in regard to internships:

an internship is more likely to be "high-impact" for students when it is intentionally organized as an activity that leads to particular learning outcomes; when students apply what they have learned in courses to work experiences, reflect on these experiences, and receive feedback

13. CAS, Professional Standards for Higher Education: Internship Programs, 310.

14. Joseph U. Leonoro, "Unpaid Interns and the Fair Labor Standards Act," National Law Review (June 22,2015 ), available online at www.natlawreview.com/article/unpaid-interns-and-fair-labor-standards-act [accessed 18 April 2018].

15. George D. Kuh, "What Student Affairs Professionals Need to Know about Student Engagement," Journal of College Student Development 50, no. 6 (Nov--Dec. 2009): 683.

16. See Jayne E. Brownell and Lynne E. Swaner, Five High-Impact Practice: Research on Learning Outcomes, Completion, and Quality (Washington, DC: Association of American Colleges and Universities, 2010); George D. Kuh, High-Impact Educational Practices: What They Are, Who Has Access to Them, and Why They Matter (Washington, DC: Association of American Colleges and Universities, 2008). The other educational practices cited are first-year seminars and experiences, common intellectual experiences, learning communities, writing-intensive courses, collaborative assignments and projects, undergraduate research, diversity/ global learning, service learning and community based learning, and capstone courses and projects.

17. Kuh, High-Impact Educational Practices, 14-17; O’Neill, "Internships as a High-Impact Practice," 4-5. 
that helps them to improve; when students build mentoring relationships with supervisors, faculty, and peers; when students are exposed to differences across people and in ways of thinking; and when students are asked to use their experiences to clarify their values, interests, and personal goals - including, in this case, their values, interests, and goals related to careers. ${ }^{18}$

\section{Rethinking Internships}

To better partner with academic institutions, ideally, special collections and archives internship host sites will provide high-impact experiences that take students beyond skills-based learning and resume-building and will create a mentored environment that fosters students' personal and academic growth. To do this, internship supervisors need to approach project and program design from a pedagogical rather than a project-based lens. Literature for library and archival internship host sites and supervisors often discuss the importance of creating appropriate projects for students. For example, Bastian and Webber's Archival Internships: A Guide for Faculty, Supervisors, and Students advises site supervisors to consider project length, levels of difficulty, and the ability to produce a finite product like a finding aid or digitized collection as part of the internship. ${ }^{19}$ While Bastian and Webber and other literature on internships acknowledge the importance of internship sites and supervisors in providing practical learning environments for students, little advice has been given to internship providers on how to design internship experiences that meet the higher education best practices and standards for internship programs described above.

At Perry Special Collections, the desire to create internships with a primarily educational purpose that included elements of high-impact practice led to reworking the internship program from a goal-focused perspective, based on principles of backward design. The backward design framework was described by Grant Wiggins and Jay McTighe in their 1998 book, Understanding by Design (revised 2005), as an approach for curriculum planning. Wiggins and McTighe encourage teachers to think about learning goals before making decisions about course content and structure. In their three-stage model, instructors first identify the desired results of their curriculum - the "why" behind learning — and then consider how to assess that learning before settling on what or how they will teach, including content choices and learning activities. ${ }^{20}$ To apply this method to the Perry Special Collections internship program, it was necessary to review academic standards for intern-

18. O’Neill, "Internships as a High-Impact Practice," 5.

19. Bastian and Webber, Archival Internships: A Guide for Faculty, Supervisors and Students, 39-40.

20. Grant Wiggins and Jay McTighe, Understanding by Design, Expanded Second Edition (Alexandria, VA: Association for Supervision and Curriculum Development, English, 2005), 17-21. 
ships as well as the learning outcomes created by the BYU academic programs that our interns most frequently major in, ${ }^{21}$ and then to consider the following: What are the learning goals of a Special Collections internship program, particularly one that caters to undergraduates? How can the Perry Special Collections internship program contribute to high-impact, experiential learning at BYU? What knowledge or skills should students retain as a result of the Special Collections internship?

In answer to these questions, three key educational goals or objectives were designed that Perry Special Collections intends to teach students through our particular undergraduate internship program. The first educational objective is transmitting professional values and knowledge. An undergraduate internship should introduce key professional theories and values related to archives and rare books librarianship to provide context to assigned tasks and to allow students to reflect on the major values, trends, and functions of the profession as well as potential career goals. The second educational objective is teaching and reinforcing students' library skills. Undergraduates come to the internship program with varying levels of familiarity with libraries, archives, and primary source research, and only some students may plan to pursue a graduate degree in library science. The internship should not just train undergraduates to do library tasks; it should allow them to become better writers, researchers, and library users-thereby reinforcing skills students are currently learning in their undergraduate major and that will serve them well no matter what path they take after their undergraduate education. The final educational objective is teaching job-based skills. The internship program should introduce students to some of the core competencies of the archives and special collections profession through a combination of mentoring and assigned tasks, with an emphasis on the interns' experiential learning rather than the curators' to-do list.

From these categories, a statement of purpose for the internship program was created, in parallel with the program statements BYU has created for various academic majors and minors. This statement of purpose guides the creation programwide student learning goals and the creation and implementation of projects for interns each semester:

\section{Undergraduate internships in the L. Tom Perry Special Collections are designed to broadly introduce students to the fields of archives and special collections librarianship as they pursue their academic and career interests. Students who successfully complete the internship will experience the day-to-day operations of a special collections library, in-}

21. Available publicly at https:/ / learningoutcomes.byu.edu/ [accessed 18 April 2018]. Perry Special Collections most frequently accepts interns who are majoring in the History, Family History, English, and Art History BA programs. 
cluding collection development, outreach, and reference work, and will learn more about the professional skills and values of archivists and rare book librarians. Interns will also improve their library research skills, including primary source research skills, and will practice broad job-based skills related to archives and rare books librarianship.

Based on this statement of purpose, seven units were established for both the Archival and Rare Books internship tracks. Each unit aims to introduce undergraduates to the basic skillsets and professional knowledge base required of Special Collections professionals as well as to give interns the chance to practice academic and professional skills. Several learning outcomes were developed for each of the seven units to guide students and their mentors through the knowledge and skills that interns are expected to develop during the course of the internship (see appendix A). These units are:

- Collection Development/Appraisal

- Bibliographic Description (for Rare Books Interns) or Arrangement and Description (for Archival Interns)

- Reference

- Introduction to Other Professional Tracks

- Curatorship

- Outreach

- Conference Presentation

The first two units provide a more intentionally designed learning experience for many of the types of tasks curators were already assigning undergraduate interns (such as low-level collection development, archival processing, or creating online bibliographies of frequently requested sources). The Reference and Outreach units ensure that interns get to learn about two other major functions of the department-something that didn't often happen under the old internship structure. The Curatorship and Introduction to Other Professional Tracks units are designed to introduce students to key values, practices, and career tracks in the special collections professions through assigned readings, discussion, and shadowing opportunities or tours with library staff in closely aligned departments like Digital Imaging, Cataloging, and Conservation.

The Conference Presentation unit was added as a way to assess interns' learning across the internship apart from successful project completion and feedback opportunities from unit supervisors and mentors. At the end of each semester, Perry Special Collections hosts a miniconference where interns report their learning experiences in a formal presentation to library staff and faculty. The presentations allow for self-reflection, a key ingredient in high-impact educational practice. Stu- 
dents often mention the projects that most excited or challenged them and discuss how the internship has influenced their academic or career goals. The conference also facilitates assessment beyond the end-of-semester evaluation form that students are asked to complete, or the academic evaluation forms that are required by many (but not all) of the interns' academic departments. Presentations allow mentors and the internship coordinator to measure how well interns are meeting learning outcomes and how students contextualize the various skills and concepts introduced during the internship. As part of formal assessment efforts, a simple rubric was designed for the final presentation to track students' learning related to professional values and job-based skills (see appendix B).

Learning activities during the internship - individual assignments in each internship unit-are still sometimes designed on an ad hoc basis in the redesigned program, especially in the Collection Development and Description Units. Curators who supervise these units are asked to consider the learning outcomes for the relevant unit in choosing appropriate projects and are also encouraged to allow interns to create at least one formal product as part of the project, such as a bibliography, research paper, or finding aid. In other units, learning activities are more standardized. Interns are assigned to spend two weeks working at the reference desk in the Reference Unit; in the Curatorship unit, interns are assigned three sets of readings related to archives and rare books librarianship. The Perry Special Collections department chair leads monthly reading group discussions with the students that are also open to department staff and faculty. The readings and discussions cover key values, practices, and career tracks in the special collections professions. In the Outreach unit, students are required to shadow or assist with a Special Collections instruction session or class presentation, though this is sometimes harder to arrange during the summer when there are fewer presentations scheduled. The interns are also given the task of curating a small, two- or three-case exhibit that they mount in the department's lobby galleries. They are provided with a general topic for the exhibit but must do the research, item selection, and writing for the exhibit themselves. For example, the winter semester 2016 intern cohort were assigned an exhibit for Black History Month; they created an exhibit based around a recently donated collection of memorabilia related to George Washington Carver and Booker T. Washington. The exhibit curation assignment asks the interns to exercise their primary source research skills as well as their writing and collaborative skills and to act as interpreters of special collections material. During the exhibit planning, they interact with library conservators and collection management staff to learn about the importance of collection care and security. After the exhibit goes up, the interns work with the staff member who manages the department's social media accounts to promote the exhibit on Perry Special Collections' blog and through Facebook, Twitter, and Instagram. 
Structurally, one other major change to the undergraduate internship program structure is that all undergraduate interns report to a single curator, the department internship coordinator, even though they may be assigned to work with different faculty and staff while working on the various internship units. This realignment has been beneficial in ensuring that all the interns receive a uniform orientation to the internship and that they have a primary contact for communication and instruction, especially as students move from unit to unit. Having all interns report to the internship coordinator also facilitates assessment by having a single person act as clearinghouse for evaluations and grades for their academic departments.

\section{Assessing the Program}

The new internship program began in winter semester 2016, not long before the university rolled out high-impact practices campuswide through the "Inspiring Learning Initiative" for the 2016-2017 academic year. ${ }^{22}$ Since the redesign, feedback has been highly positive from the undergraduate students as well as the curators and other staff who work with them. The interns have been energized by the wide variety of assignments, including group projects; the Reference, Outreach, and Reading Group units have been rated highest in student surveys. Students have appreciated getting to know working library and archives professionals during the internship units, particularly the reading group; they also feel that they gain a good understanding of potential career opportunities available to them, such as library work or public history, because of their participation in the internship. Overall, the interns have expressed a basic understanding of the major practices, values, and skillsets of the archives and rare books professions and have been able to articulate both what and why archivists and librarians do what they do. They often report that their facility with library research tools has greatly improved, enhancing their academic work ("I wish I learned about this earlier in my program" is a common refrain), and that they make connections between their internship projects and academic work. Interns also mention their appreciation for building employment-related skills and the ability to produce an identifiable product like a finding aid, social media post, exhibit captions, or research guide to include in portfolios or resumes.

In addition, the internship appears to be making an impact on students' immediate career and employment choices. During the first eight semesters of the redesigned program, Perry Special Collections hosted 23 undergraduate interns, including two students from neighboring schools in the state. In formal evaluations and final presentations, a number of interns have expressed that the program solidified their interest in libraries, museums, or public history as a career; students also report that specific internship units helped them discern personal strengths and prefer-

22. See Kevin J. Worthen, "Inspiring Learning” (address, August 22, 2016), available online at https:// speeches.byu.edu/talks/kevin-j-worthen_inspiring-learning/ [accessed 18 April 2018]. 
ences for certain types of work (for example, some students discover an aptitudeor a dislike-for customer-facing work after time at the reference desk). Five of our former interns have chosen to apply to library school after graduation and another was hired as a library paraprofessional after completing her bachelor's degree. A number of interns found student employment in the library or in museums and public history projects elsewhere on campus after completing their internships. Thus, based on formal and informal feedback, the redesigned internship units appear to support the internship program's main learning objectives and provide a high-impact educational experience for the students who participate.

Creating learning objectives and intentionally designed learning experiences has enabled Perry Special Collections to better mentor our undergraduate interns. Overhauling our internships by focusing up front on designing specific program goals and learning outcomes took a lot of initial work, but it has made a demonstrable improvement in the experiences we offer students. Apart from solving some of the structural weaknesses of the haphazard, task-oriented internships we previously offered, we feel confident that we are providing a richer learning experience for the undergraduates and are adhering to best practices for internships in higher education. Our interns not only learn valuable work skills specific to libraries and archives, they build interpersonal and academic skills and are given meaningful opportunities to reflect on the core values that underpin their daily work.

Another benefit of redesigning our internship program is strengthened relationships with academic department internship coordinators and faculty on campus, ${ }^{23}$ who have anecdotally shared their observations of positive educational and personal growth in students participating in the Perry Special Collections internship program and their willingness to recommend our internships to motivated students. After nearly three calendar years of providing the redesigned internships, plans are being made to seek more formal feedback from academic department internship coordinators to potentially enhance the internship program. Perry Special Collections is also planning to review the internship reading group to see if assigned readings are still effective and to begin informal discussions about providing project supervisors with standardized rubrics to better assess interns' learning and performance in each internship unit.

\section{Conclusion}

Many special collections libraries and archives find themselves relying on the work of interns and other volunteers to complete projects and advance their daily work. Whether host sites offer internships to graduate-level or undergraduate students,

23. All academic majors at BYU have a faculty internship coordinator; several programs have formal internship offices with additional staff coordinator(s). 
they are responsible for creating work environments that contribute to interns' academic, personal, and professional growth. When host sites, particularly those offering unpaid internships, approach internships with purposeful attention to designing educational experiences, providers can be confident that they are offering high-quality internships that comply with academic and legal best practices and that support interns' in-class education. Since the internship program at Perry Special Collections primarily draws participants from a handful of majors on our own campus, it has been easy to align our program's learning goals with the educational initiatives and learning outcomes set by our parent institution, but we feel the redesign process has allowed us to demonstrate to university faculty and administrators that Special Collections is committed to advancing BYU's high-impact experiential learning initiatives, as well as mitigating risk from a human resources standpoint. More important, the renewed focus on learning goals and high-impact educational practices strongly improves the internship experience for both Perry Special Collections as a host institution and our interns.

While other libraries and archives might not face the exact set of logistical and administrative concerns we faced at BYU, similar internship design principles can be applied to MLS internships. Host site supervisors should be in dialogue with MLS program internship advisors or coordinators about their program goals and learning outcomes, and these discussions can inform the design of high-impact experiential learning activities for interns. Once host sites understand the learning goals of academic programs, they can identify the "why" behind internships - the specific knowledge and experience students should gain, not just the amount of work the host site hopes the intern can accomplish. Using a pedagogical lens, supervisors can begin to assess how to teach specific knowledge and skills over the course of the internship and to evaluate the effectiveness of the projects and activities that are typically assigned to student interns. At Perry Special Collections, our review led to small changes in the types of assignments given to interns and in the way the program was administrated, but redesigning our programs from the standpoint of learning goals has made a positive impact on the effectiveness of our internship program. Identifying the knowledge and skills that students should acquire during the internship before selecting projects and tasks allows internship providers to create a learning-driven environment where interns can thrive, both during their internship and later as they enter their chosen profession. 


\section{APPENDIX A. \\ L. Tom Perry Special Collections Undergraduate Internship}

\section{Units and Learning Outcomes}

Based on a 3-credit academic internship (120 hours)

\section{Collection Development/Appraisal}

Sample Assignments (Rare Books Internship):

- Explore the major collecting areas on Special Collections' website

- Work with a rare book curator to understand their collecting policy or policies and how those policies relate to other collections

- Work with the curator to appraise potential purchases or donations of print material or to evaluate an existing collection and recommend potential new acquisitions for Special Collections

Sample Assignments (Archives Internship):

- Explore the major collecting areas on Special Collections' website

- Work with an archival curator to understand their collecting policy or policies and how those policies relate to other collections

- Work with the curator to appraise potential new acquisitions or unprocessed backlog collections, or help identify potential donors of archival material

Learning Outcomes:

- Interns will demonstrate knowledge of Special Collections' major collecting areas

- Interns will be able to describe key features of the collection development policy for at least one collecting area

- Interns will understand the process of evaluating and acquiring new material for Special Collections

Time Spent: 15 hrs.

\section{Bibliographic Description/Arrangement and Description}

Sample Assignments (Rare Books Internship):

- Under the supervision of a rare book curator, explore 1-2 print or online bibliographies or lists related to their collections and learn how to evaluate bibliographic information in these bibliographies and compare it to the library catalog

- Create a handlist of rare books or other materials from Special Collections

- Create entries for an online bibliography

Sample Assignments (Archives Internship):

- Work under supervision of Central Processing Unit Supervisor and/or a 
manuscripts curator to inventory and/or describe an archival collection

- Rehouse archival material

- Receive training in archival descriptive tools and standards

Learning Outcomes (Rare Books Internship):

- Interns will understand the importance of bibliographic description for collection development, security, and discovery

- Interns will become familiar with tools and resources the library uses to describe its collections (catalogs, databases, collection guides)

- Interns will recognize rare print material description standards

Learning Outcomes (Archives Internship):

- Interns will develop the knowledge and experience necessary to arrange and describe archival materials

- Interns will become familiar with archival processing and description tools

- Interns will become familiar with archival description standards

Time Spent: 25 hrs.

3. Reference

Sample Assignment:

- Under the supervision of the Reference Specialist and the reference student employees, work at the front desk to assist patrons in accessing Special Collections material

Learning Outcomes:

- Interns will provide customer-oriented service to Special Collections material

- Interns will become familiar with the range of reference services provided to patrons

- Interns will become familiar with common tools used to help patrons access material, including databases, the library catalog, and the finding aids database

Time Spent: 20 hrs.

\section{Introduction to Other Professional Tracks}

Sample Assignments:

- Interns will interview/shadow a curator in Special Collections whose responsibilities correspond to the other internship track (manuscripts/rare books) about their responsibilities and skillsets

- Interns will be given collections management tasks

- Interns will shadow other library professionals in the Lee Library

Learning Outcomes:

- Interns will be able to articulate the differences and similarities between curating archival material and rare printed material

- Interns will recognize the behind-the scenes work that is done in libraries and archives 
- Interns will understand the variety of job types available in libraries and archives

Time Spent: $5-8$ hrs.

\section{Curatorship}

Sample Assignments:

- With other interns, complete a series of readings on the archival and special collections professions and discuss them with Special Collections faculty and staff in a group setting

Learning Outcomes:

- Interns will understand the key values and practices of special collections professions

- Interns will be able to articulate professional values, skillsets, and career paths in the special collections professions

Time Spent: 4-5 hrs.

\section{Outreach}

Sample Assignments:

- With other interns, create a small case exhibit under the supervision of a curator

- Study Special Collections' social media policies and create at least one posting on an official Special Collections account

- Assist a curator with a class presentation

Learning Outcomes:

- Interns will understand why and how Special Collections tries to reach various audiences both on and off campus

- Interns will work collaboratively

- Interns will understand how special collections professionals interpret materials to a broad audience

Time Spent: 30 hrs.

\section{Conference Presentation}

Assignment:

- Interns will prepare and give an 8-minute presentation on their projects to Special Collections and other library employees

Learning Outcomes:

- Interns will articulate the variety of skills and knowledge gained during the internship in a professional manner

Time Spent: $2.5 \mathrm{hrs}$. 


\section{APPENDIX B. Internship Presentation Rubric}

\begin{tabular}{|l|l|}
\hline 5 Excellent & $\begin{array}{l}\text { Intern shows a high level of reflection on internship experience } \\
\text { and introduction to the profession, including relevance to } \\
\text { career exploration or connections to academic experience or } \\
\text { coursework. Provides evidence of specific skills learned or } \\
\text { insights gained during the internship. Specific information } \\
\text { is given to support conclusions. There is strong evidence of } \\
\text { preparation, organization, and enthusiasm. The visual aid is } \\
\text { used to make the presentation more effective. Questions from } \\
\text { the audience are clearly answered with specific and appropriate } \\
\text { information. }\end{array}$ \\
\hline 4 Very Good & $\begin{array}{l}\text { The student reflects on internship experience and introduction } \\
\text { to the profession, including relevance to career exploration or } \\
\text { connections to academic experience or coursework. Provides } \\
\text { evidence of specific skills learned or insights gained during } \\
\text { the internship. An adequate amount of information is given } \\
\text { to support conclusions. There is evidence of preparation, } \\
\text { organization, and enthusiasm. The visual aid adequately } \\
\text { advances the presentation. Questions from the audience are } \\
\text { answered clearly. }\end{array}$ \\
\hline 2 Limited & $\begin{array}{l}\text { The student fails to adequately describe the internship } \\
\text { experience and evidence of learning. No conclusions are drawn. } \\
\text { Evidence of preparation and organization is lacking. The visual } \\
\text { aid may or may not advance the presentation. Questions from } \\
\text { the audience are answered inadequately. } \\
\text { the profession, and provides evidence of learning, but supporting } \\
\text { information is not as strong as a } 4 \text { or } 5 . \text { There is some indication } \\
\text { of preparation and organization. The visual aid adequately } \\
\text { advances the presentation. Questions from the audience are } \\
\text { answered adequately. }\end{array}$ \\
\hline 3 Good & $\begin{array}{l}\text { The student makes a presentation that does not adequately } \\
\text { describe the internship experience and shows little evidence of } \\
\text { learning. The topic is unclear, and no adequate conclusions are } \\
\text { stated. The delivery is difficult to follow. There is no indication } \\
\text { of preparation or organization. Questions from the audience } \\
\text { receive inadequate, or no, response. }\end{array}$ \\
\hline
\end{tabular}

